\title{
Генезис высокоуглеродистых шунгитоносных пород - обзор
}

\section{Дейнес Ю.Е., Первунина А.В.}

Институт геологии КарНЦРАН, Петрозаводск, deines@krc.karelia.ru; aelita@krc.karelia.ru

Аннотация. В статье обсуждаются основные принципы генетического изучения месторождений шунгитов и максовитов. Рассмотрены некоторые концепции формирования залежей высокоуглеродистых пород в Онежской палеопротерозойской структуре (Карелия). Представлен перечень прямых и косвенных геологогенетических признаков развития инъекционной складки. Приводятся аргументы в пользу обнаружения крупного тела максовитов в пределах участка Тетюгино (Онежская структура, Карелия). Показано, что гипотетическое предположение о существовании крупной купольной структуры, не разрушенной эрозией, имеет под собой прочное методологическое обоснование.

Ключевые слова: шунгит, максовит, палеопротерозой, заонежская свита.

\section{The genesis of high-carbon shungite rocks - review}

Deines Yu.E., Pervunina A.V. IG KRC RAS, Petrozavodsk, deines@krc.karelia.ru; aelita@krc.karelia.ru

\begin{abstract}
The main principles of the genetic study of shungite and maksovite deposits are discussed. Several modern concepts of the formation of high-carbon rock deposits in the Paleoproterozoic Onega structure are reviewed. A list of direct and indirect geological-genetic indications of the development of an injection fold is presented. Evidence of a large maksovite body in the Tetyugino area (Onega structure, Karelia) are provided. It is shown that the hypothetical assumption of the existence of a large dome structure not destroyed by erosion has a solid methodological rationale.
\end{abstract}

Key words: shungite, maksovite, Palaeoproterozoic, Zaonega Formation.

В работе рассмотрены основные принципы и способы организации экспериментальной и исследовательской деятельности при решении проблем генезиса месторождений максовитов и шунгитов ${ }^{1}$.

Месторождения максовитов на территории Онежской палеопротерозойской структуры представлены купольными залежами и детально изучены на примере Максовского месторождения. В структурном отношении это близкая к изометричной антиклинальная складка четвертого порядка с амплитудой в центральной части 120 м. На месторождении отмечена характерная зональность в распределении углерода и минерального вещества. Месторождения шунгитов - это субпластовые тела небольшой мощности (до 4.5 м), субсогласные по отношению к вмещающим породам, исследованы на примере месторождения Шуньга.

Существует несколько гипотетических представлений о происхождении месторождений. Первооткрыватель шунгитов А.А. Иностранцев доказал, что исследуемое вещество в составе шунгитов является представителем нового крайнего члена в ряду аморфного углерода («...уже не антрацит, но еще не графит...») (Иностранцев, 1886). Оппоненты, специалисты-угольщики, на основании визуальных характеристик, состава и теплотворной способности шунгита настаивали на аналогии с антрацитами. Б.Ф. Мефферт (1919) отмечает характерную особенность Шуньгского месторождения - наличие спорадических тонких прослоев блестящего антрацита, названного А.А. Иностранцевым шунгитом.

Н.И. Рябов (1933) рассматривал шунгиты как древнейшие органогенные образования - сапропелиты, сформировавшиеся при увеличении давления вышележащих пород на горизонты с органическим веществом (ОВ). Наиболее подвижное вещество выдавливалось в верхние горизонты, а затем осуществлялась дифференциация в пределах слоя. Предположение о биогенном происхо-

\footnotetext{
${ }^{1}$ Максовиты и шунгиты - высокоуглеродистые породы, содержащие от 10 до 45 \% и от 45 до 80 \% углерода (шунгитового вещества) соответственно; плотные, пелитоморфные. Шунгиты имеют параллелепипедальную отдельность, напоминают антрацит. И те, и другие отнесены к сапробитумолитовым породам (Филиппов, 2002).
} 
ждении пород Шуньгского месторождения на основе исследования состава шунгитового вещества (ШВ) было выдвинуто Н.А. Орловым (Орлов и др., 1934), а затем К. Ранкама (Rankama, 1948). П.А. Борисов (1956) считал шунгитоносные породы (ШНП) метаморфизованными сапропелитами. Ю.К. Калинин (Калинин, Горлов, 1975) предполагал, что механизм накопления ШВ в осадочных породах связан с сорбцией углеводородов (УВ). Позже в монографии (Калинин и др., 2008) высказано предположение о вулканической природе Зажогинского месторождения. Образование месторождений по В.И. Горлову (1984), обусловлено неравномерными вспышками биопродуктивности в мелководных участках бассейна с относительно спокойным гидродинамическим режимом. В представлении В.П. Михайлова и С.В. Купрякова (Михайлов, Купряков 1985) «УВ типа асфальта», образующиеся в кровле очагов базальтовой магмы, по глубинным разломам поступали на дно морского бассейна, где накапливались совместно с осадочным материалом. Локальные тела формировались вблизи источников вещества «из пересыщенных кремнеземом асфальтовых терм». П.Ф. Иванкин (Иванкин и др., 1987) образование ШНП связывает с процессом замещения осадочных пород УВ, поступающими в бассейн осадконакопления в результате активной мантийной дегазации. Л.П. Галдобина придерживалась эндогенной гипотезы в формировании месторождений высокоуглеродистых пород Онежской палеопротерозойской структуры (Галдобина, 1987; 1991). А.М. Ахмедов (1997) считал, что тела максовитов - это сапропелевые осадки, накопленные в локальных депрессиях стагнационных стратифицированных бассейнов, которые возникали при относительном движении блоков дна бассейна. Вероятное происхождение месторождений максовитов за счет «горения метана» предположил В.И. Березкин (2001).

В работе углепетрографов И.Б. Волковой и М.В. Богдановой (Волкова, Богданова, 1985) приводятся доводы в пользу принадлежности шунгитов и антраксолитов Шуньгского месторождения к гумолитам. Фотографии поверхностей травления интерпретируются как «растительные структуры, весьма сходные со строением древесины» $(1985$, с, 100$)$. В действительности авторы выявили надмолекулярные структуры похожие на клетки древесины. Это типичные для высокоуглефицированных битумов структуры мезофазы (Khavari-Khorosani, Murchison, 1979). После объявления об открытии фуллеренов в шуньгском антраксолите (Buseck et al., 1992) появилось множество публикаций физиков, в которых авторы высказывают представления о генезисе шунгитов (Березкин, 2001; Ковалевский, 2009).

В диапировой модели (Филиппов, 2000), сторонниками которой являются авторы данной статьи, Максовское и Шуньгское месторождения - это структуры, сформированные по горизонтам, представленным первичными сапропелевыми отложениями: купол - промежуточная, а субпластовые тела - завершающая (экструзивная) стадии развития складок нагнетания. Предположение о генетической близости двух месторождений базируется на том, что в пределах Максовской залежи фиксируются локальные области, сложенные шунгитами, появляющимися при дифференциации вещества по плотности, а в перекрывающих шунгитоносных горизонтах, сохранившихся на периферии, есть признаки перемещения материала, близкого по составу к шунгитам. Коллективом авторов (Филиппов и др., 2009) на примере Максовского месторождения показано, что время внедрения силлов габбродолеритов было более поздним по отношению к завершению формирования купольной структуры.

Основные методологические принципы доказательства истинности разрабатываемой диапировой модели базируются на том, что структуры, сформированные по горизонтам сапропелевых осадочных пород, должны иметь ряд характерных прямых и косвенных признаков. Прямые признаки, вытекающие из теории диапиризма: обязательная приуроченность структур четвертого порядка (куполов) к антиклиналям третьего порядка; наличие краевых синклиналей; характерные литологические особенности пород, фиксирующие массовое перемещение и дифференциацию органоминерального вещества в пределах купола (состав, текстуры, структуры); в случае вероятной деформации покрышки - локальные разломы и др. Косвенные признаки, геофизические и геоморфологические, - отражение в геофизических полях и в современном рельефе генетических признаков. Генетическая близость купольных залежей максовитов и субпластовых тел шунгитов доказывается пу- 
тем выявления примеров массовой экструзии из купольных структур вещества, по составу близкого к шунгитам (Филиппов и др., 2016). Для субпластовых проявлений шунгитов, рассматриваемых в модели в качестве элементов диапировых шляп, найдены структурные признаки (мелкая гофрированность пластов), свидетельства движения вещества под давлением (будинирование слоя доломитов, следы течения), литологические (состав, текстура, структура шунгитов) и геохимические признаки (изотопный состав углерода и др.).

Многие положения диапировой модели с развернутыми доказательствами подробно отражены в публикациях и здесь не обсуждаются. Это касается исследования признаков первичного коллоидного состояния максовитов и шунгитов, теоретического обоснования возможности развития купольных структур по горизонтам сапропелитов, текстурных, структурных, литохимических, геохимических и геофизических признаков, интерпретируемых как следствия формирования складок нагнетания и полидиапировых внутренних структур. Экспериментально подтверждено существование системы купольных структур в Толвуйской синклинали Онежского синклинория (Филиппов и др., 2004).

Примером использования методологических принципов, нацеленных на развитие положений основной гипотезы, может служить предположение о вероятном существовании в Толвуйской синклинальной структуре куполов, аналогичных Максовскому, но не выходящих на уровень современного эрозионного среза. Исследования, проведенные на участке Тетюгино, изложены в работе М.М. Филиппова и Ю.Е. Дейнес (2012).

На участке выявлены структурные, литологические и литохимические признаки складки нагнетания. Краевая синклиналь, проявляется в современном рельефе в виде областей пониженных отметок, опоясывающих с юга и северо-запада локальную область с относительно высокими отметками и крутыми углами падения слоев (до $35^{\circ}$ ), не характерными для структуры третьего порядка. В области развития краевой синклинали мощность шестого горизонта шунгитоносных пород существенно меньше. Максовиты и шунгиты нередко имеют флюидальные текстуры. Есть примеры краевой брекчии: обломки известняков и алевролитов в шунгитах, захваченные при перемещении пластичного материала из вмещающих пород. Мощность высокоуглеродистых пород шестого горизонта по направлению к предполагаемому центру складки быстро увеличивается. Содержание углерода в породах существенно превышает рядовые концентрации в шунгитоносных горизонтах (в среднем по шестому горизонту более 46 \%, а максимальные - до 55 \%), в краевой части залежи концентрация углерода меньше по сравнению с участком, приближенным к центру, в кровле - содержание более высокое по сравнению с подошвой.

Известно, что над соляными купольными структурами формируется сложная система деформаций покрышки (Brinkman et al., 1968). При физическом моделировании процесса в покрышке формируется центральный горст, обрамленный симметрично расположенными грабенами, причем периферийные грабены могут быть развернуты вплоть до обратного залегания слоев; в сводовом горсте горизонтальное залегание пород сохраняется; в грабенах - залегание слоев всегда нарушено, слои сильно деформированы. Реальная система разломов описана в работе (Davison et al., 1993).

На участке Тетюгино выявлены признаки, которые, по мнению авторов (Филиппов, Дейнес, 2012), свидетельствуют о влиянии купольной структуры на перекрывающие горизонты. Элементы залегания лидитов и доломитов резко меняются, отражая блоковое строение участка и разворот блоков относительно своей оси. Уступы рельефа высотой до 1.5 м, имеют разную длину и направление и расположены на разных гипсометрических отметках. Они отождествляются со стенками блоков, смещенных по вертикали относительно друг друга. Между блоками выявлены зоны мощностью до 4 м, края которых сложены интенсивно брекчированными лидитами и доломитами, сцементированными шунгитом и антраксолитом, а центральная часть - породой, по составу близкой к шунгитам. Остроугольные обломки брекчий смещены от своего первоначального положения на некоторое расстояние и частично развернуты вокруг своей оси, что указывает на движение флюида под давлением. Края обломков известняка пропитаны битумом, что свидетельствует о высоком давлении флюида. Предполагается, что процесс брекчирования развивался при механическом воздействии купола на перекрывающие горизонты. Не случайно интенсивность брекчирования затухает при удалении 
от предполагаемого центра структуры. Уступы рельефа в серо-восточной части участка отмечаются высокими градиентами потенциалов естественной поляризации. О наличии субмеридиональных разломов свидетельствует также контрастное распределение скорости прохождения преломленных волн. По данным электропрофилирования в модификации срединного градиента, на участке выделена достаточно симметричная область с пониженным сопротивлением. Такой характер распределения электрических свойств сохраняется и при пересчете данных на глубину. Центр аномалии можно считать проекцией центра купольной структуры. Региональный геофизический репер (интервал с повышенной радиоактивностью), фиксируется на участке в виде отдельных пятен, которые можно считать блоками-грабенами, смещенными относительно друг друга по вертикали. Таким образом, на участке выявлены геофизические признаки, которые можно интерпретировать как следствие развития купольного тела, не выходящего на эрозионный уровень.

На примере участка Тетюгино продемонстрирована методология сбора и анализа геологогеофизических материалов. В результате выявлены прямые и косвенные признаки диапирового тела, оценена ведущая длина волны для соседних купольных структур. В работе М.М. Филиппова с соавторами (Филиппов и др., 2016) приведены данные о шунгитоносных породах участка Тетюгино, имеющих основные признаки флюидогенного генезиса: форму проявления, текстуру, минеральный, химический и изотопный состав углерода. К таким породам отнесены брекчии в надкупольных разломах (диапировый меланж) и локальные субпластовые тела - инъекции метасапропелитов. Показано, что наиболее вероятный источник флюидолитов - Мельничный купол, а основная движущая сила перемещения вещества - аномально высокое пластовое давление, развивающееся при катагенеза органического вещества и генерации углеводородов. Следовательно, гипотетическое предположение о существовании крупной купольной структуры, не разрушенной эрозией, имеет под собой прочное методологическое обоснование.

Приведенный пример анализа геологической информации может быть распространен на другие участки Толвуйской синклинали, а также на другие аналогичные структуры Онежского синклинория, поскольку диапировая модель открывает возможность значительного расширения поисковых признаков, использование которых на практике должно значительно повысить достоверность прогноза новых месторождений, ускорения и удешевления поисков, повышения качества разведки.

\section{Литература}

1. Ахмедов А.М. Бассейны черносланцевой седиментации раннего протерозоя Балтийского щита (этапы развития, режимы седиментации, металлоносность): Автореф. дисс. д. г.-м. наук. СПб. 1997. 353 с.

2. Березкин В.И. К вопросу о генезисе карельских шунгитов в связи с особенностями их структуры // Геохимия. 2001. Т. 39. № 3. С. 253-260.

3. Борисов П.А. Карельские шунгиты. Петрозаводск. 1956. 92 с.

4. Волкова И.Б., Богданова М.В. Шунгиты Карелии // Сов. Геология. 1985. № 10. С. 93-100.

5. Галдобина Л.П. Металлогения шунгитсодержащих и шунгитовых пород Онежской мульды // Материалы по металлогении Карелии. Петрозаводск. 1987. С. 100-113.

6. Галдобина Л.П. Предполагаемый канал поступления углеводородных флюидов в нижнем протерозое Онежской структуры // Геология и рудогенез докембрия Карелии. Петрозаводск. 1991. С. 18-23.

7. Горлов В.И. Онежские шунгиты / Дисс. канд. г.-м. наук. Петрозаводск. 1984. 226 с.

8. Иванкин П.Ф., Галдобина Л.П., Калинин Ю.К. Шунгиты: проблемы генезиса и классификации нового вида углеродистого сырья // Сов. Геология. 1987. № 12. С. 40-47.

9. Иностранцев А.А. О шунгите // Горн. журн. 1886. № 2. С. 35-45.

10. Калинин Ю.К., Горлов В.И. Вещественный состав шунгитового вещества // Шунгиты Карелии и пути их комплексного использования. Петрозаводск: КарНЦ РАН. 1975. С. 44-55.

11. Калинин Ю.К., Калинин А.И., Скоробогатов Г.А. Шунгиты Карелии - для новых стройматериалов, в химическом синтезе, газоочистке, водоподготовке и медицине. СПб. 2008. 218 с.

12. Ковалевский В.В. Шунгит или высший антраксолит? // ЗРМО. 2009. № 5. С. 97-105.

13. Мефферт Б.Ф. Шунгинское месторождение антрацита в Повенецком уезде Олонецкой губернии // Естественные производительные силы России. 1919. Т. 4. Вып. 20. С. 275-288. 
14. Михайлов В.П., Купряков С.В. Отчет о результатах детальной разведки юго-восточной (Максовской) залежи Зажогинского месторождения шунгитовых пород за 1982-85 гг. Фонды ККГРЭ. Петрозаводск, 1985. $138 \mathrm{c}$.

15. Орлов Н.А., Успенский В.А., Шаховцев И.Н. Опыт химического исследования шунгита // ХТТ. 1934. Т. 5. Вып. 7. С. 601-619.

16. Рябов Н.И. Отчет о геолого-разведочных работах на Шуньгском месторождении шунгита за 1932-33 гг.: Фонды КарНЦ РАН. Петрозаводск. 1933. С. 22-25.

17. Филиппов М.М. Модели формирования месторождений шунгитоносных пород Онежского синклинория. 2000. Автореф. дисс. д. Г-м. н. 310 с.

18. Филиппов М.М. Шунгитоносные породы Онежской структуры. Петрозаводск: Карельский научный центр РАН. 2002. 280 с.

19. Филиппов М.М., Бискэ Н.С., Первунина А.В., Дейнес Ю.Е. Сопоставление известных и новых данных о геологическом строении Максовского месторождения шунгитоносных пород // Геология и полезные ископаемые Карелии. Вып. 12. Петрозаводск: КарНЦ РАН. 2009. С. 130-142.

20. Филиппов М.М., Дейнес Ю.Е. Традиционные и эвристические подходы к интерпретации геологогеофизических материалов на перспективном для открытия месторождения максовитов участке Толвуйской синклинали // Учен. зап. ПетрГУ. Сер.: Естеств. технич. науки. 2012. № 2. С. 49-56.

21. Филиппов М.М., Дейнес Ю.Е., Лохов К.И., Первунина А.В., Лохова О.В. Новый генетический тип шунгитоносных пород палеопротерозоя Онежской структуры // Региональная геология и металлогения. Вып. 67. СПб. 2016. С. 95-106.

22. Филиппов М.М., Клабуков Б.Н., Суханов А.В. Экспериментальное определение основных параметров систем купольных шунгитоносных структур Толвуйской синклинали // Российский геофизический журнал. 2004. № 3. C. 25-30.

23. Brinkman R., Löcters H. Diapirs in western Pyrenees and Foreland, Spain // Diapirism and diapers/ Braunstein J.,O’Brien G. eds. Tulsa. 1968. P. 275-292.

24. Buseck P.R., Tsipursky S.J., Hettich R. Fullerenes from the geological environment // Science. 1992. V. 257. P. 215-217.

25. Davison I., Insley M., Harper M. et al. Physical modeling of overburden deformation around salt diapers // Tectonophysics. 1993. V. 228. P. 255-274.

26. Khavari-Khorosani G., Murchison D.G. The nature of Karelian shungite // Chem. Geology. 1979. V. 26. No 1/2. P. 165-182.

27. Rankama K. New evidence of the origin of pre-cambrian carbon // Bull. Geol. Society of America. V. 59 . № 5. 1948. P. 389-416. 